Goran Vukmirović ${ }^{1}$

Radenko Marić

Jelena Damnjanović ${ }^{3}$
JEL: F1, L81

DOI: 10.5937/industrija46-17337

UDC: 339.37

005.52:339.13(497.11)

Original Scientific Paper

\title{
Impact of Retail Market Concentration on Differences in Retailers' Productivity and Business Results
}

\author{
Article history: \\ Received: 3 May 2018 \\ Sent for revision: 9 May 2018 \\ Received in revised form: 4 September 2018 \\ Accepted: 4 September 2018 \\ Available online: 2 October 2018
}

\begin{abstract}
The aim of this paper is to define the degree of the Serbian retail market concentration and to determine the nature of the correlation between market concentration and retailers' business performances. The main task of the research is to indicate how changes in market share affect the development of the retail sector. Based on financial indicators in retail, realized turnover and profit per employee, the null research hypothesis was tested for proving a significant correlation between the size of market share of retail chains and their productivity and business results. The obtained results show the level of deviation in terms of the differences between the size of market share and productivity and the business result. There is also an obvious increase in the market share of large retail chains which has led to a decrease in the total number of small independent retailers, as well as a rise in market concentration levels. The obtained results, the conducted analyses and tests will point to the potential dangers of the concentration of the national market and define the criteria for achieving a higher degree of homogeneity. Suggestions and guidelines for future research are presented in the paper.
\end{abstract}

Key words: internationalization of retailing, market concentration, productivity, business result, retail chains.

\footnotetext{
${ }^{1}$ University of Novi Sad, Faculty of Economics in Subotica

${ }^{2}$ University of Novi Sad, Faculty of Economics in Subotica,radenko.maric@ef.uns.ac.rs

${ }^{3}$ Novi Sad Business School
}

Industrija, Vol.46, No.3, 2018 
Vukmirović G., et al: Impact of Retail Market Concentration on Differences in Retailers'

\title{
Uticaj koncentracije tržišta malopodaje na razlike u produktivnosti i poslovnom rezultatu maloprodavaca
}

\begin{abstract}
Apstrakt: Cilj ovog rada je da se odredi stepen koncentracije malopodajnog tržišta Republike Srbije, $i$ da se utvrdi priroda povezanosti između koncentracije tržišta i poslovnih performansi maloprodavaca. Osnovni zadatak istraživanja jeste da se ukaže kako promene tržišnog učešća utiču na razvoj maloprodajnog sektora. $\mathrm{Na}$ bazi finansijskih pokazatelja u maloprodaji, ostvarenog prometa i profita po zaposlenom, testirana je osnovna istraživačka hipoteza o postojanju značajne povezanosti između veličine tržišnog učešća malopodajnih lanaca i njihove produktivnosti i poslovnog rezultata. Dobijeni rezultati pokazuju nivo odstupanja u pogledu razlika između veličine tržišnog učešća i produktivnosti i poslovnog rezultata. Evidentan je $i$ rast tržišnog učešća velikih maloprodajnih lanaca koji je doveo do smanjenja ukupnog broja malih nezavisnih detaljista, kao i rasta stepena koncentracije tržišta. Na bazi dobijenih rezultata, sprovedenih analiza i testiranja ukazaće se na potencijalne opasnosti koncentracije nacionalnog tržišta $i$ definisaće se kriterijumi za postizanje većeg stepena homogenosti. Predlozi i smernice za buduća istraživanja predstavljene su u radu.
\end{abstract}

Ključne reči: internacionalizacija malopodaje, koncentracija tržišta, produktivnost, poslovni rezultat, maloprodajni lanci.

\section{Introduction}

The retail sector of the Republic of Serbia has been facing significant changes in recent years in market concentration and the strengthening of horizontal and vertical competition, which is accompanied by a continuous reduction in the number of small independent retailers (Lovreta, Končar, \& Petković, 2009). In academic research (Tansey, \& Raju, 2017; Pešić, 2015; Lukić, 2010; Goodman, Kachur, Abdulla, Bloland, Mills, 2009; Lovreta, Končar, \& Petković, 2009; Drašković, \& Domazet, 2008; Bhattacharya, 2003; AaltoSetala, 2002), the processes of retail market concentration and change of balance of power in value chains are becoming more and more current. Pešić (2015) and Ljubović, Pavlović, \& Cvijanović, (2014) define market concentration as a degree in which a small number of enterprises can significantly affect certain economic activities, such as total turnover, assets or employment. According to Lukić's research results (2010), the business performance of trading companies in the Republic of Serbia was especially influenced by the effects of concentration, by the entrance of international retail chains. According to the data of the Statistical Office of the Republic of 
Serbia, the total turnover of 15 largest retail chains in the Republic of Serbia is over $70 \%$ of the total retail business income (Statistical Yearbook, 2017).

At the global level, the trend of concentration is also becoming more and more present, the average market share of the leading 5 retail chains in the EU countries is $60.23 \%$ and ranges from the low concentrated Polish market with $26.55 \%$ to the highly concentrated market of Norway with as much as $82.25 \%$ of total market share (Petković, Lovreta, Pindžo, \& Pešić, 2016). In addition to standard retail strategies, large retail chains develop new and innovative retail formats and sales methods and achieve the basic competitive advantages on the basis of economies of scale and cost advantages in relation to small and independent retailers (Rickert, Schain, \& Stiebale, 2018; Lovreta, 2009). This affects the continuous growth of the actual volume of turnover by stores of large retail chains, as well as the reduction of the number and strength of small and medium-sized trading companies and the number of their facilities. Contrary to the decrease in the number of sales facilities, there is also a trend of increasing sales areas per retail facility. In the period 2009-2015, the average sales area per capita in the EU is constantly increasing and is estimated at $1,117 \mathrm{~m}^{2}$, while in Serbia it is about $0,58 \mathrm{~m}^{2}$ per capita (Petković et al., 2016).

The liberalization of the national retail market is directly influenced by the tendency of internationalization of the performances of leading global and European retail chains. Pešić (2015) states that out of 250 largest retailers, even $68 \%$ (or 155) of retailers internationalised their business while only 95 retail chains are nationally oriented. Integration processes in the form of horizontal and vertical integration, as well as the process of internationalization and entrance of large retail chains increase the level of concentration of the Serbian market, acquisition of independent retailers, and the reduction in the number of employees in the retail sector, which in the period 2007-2013 was 28.3\% (Petković et al, 2016). On the other hand, the studies (Usova, 2017; Petković et al, 2016; Goodman et al, 2009) show that the market concentration and the increase in the size of retail facilities are directly correlated with productivity. In the Republic of Serbia, the number of employees per retail facility increased from 76.4 to 88.2 as a result of a decrease in the number of facilities and a significant reduction in the number of employees in the market, which directly affected productivity growth (Petković et al, 2016; Pešić, 2015). Similarly, SCP paradigm (StructureConduct-Performance), founded in the USA more than half a century ago, shows that market structure directly affects the economic behaviour of companies, which in turn has an impact on business results. In such a case, the feedback effects occur so that the effect of the market can be reflected on the behaviour and structure, or behaviour can affect the market structure (Panagiotou, 2006). 
Bearing in mind the previously expressed aspects, the Subject of the Research is the analysis and evaluation of the degree of market concentration in the Republic of Serbia. Research goal is to define the nature of the correlation between differences in the size of retailers and achieved productivity and business result. The main task is to point out the problems caused by market concentration in the development of retail, especially in relation to rural and less developed environments. In such context, the analysis of the basic financial indicators was conducted on the sample of 40 largest trading companies of the Republic of Serbia, which are grouped in four stratums, according to market share in the total turnover (<1\%; $1-5 \% ; 5-15 \%$; $15 \%>)$. The analysis was done for the entire national market and especially by regions (Vojvodina, City of Belgrade, Central-South Serbia).

The paper structure comprises five parts. After introductory considerations, the most important theoretical aspects of the market concentration problem were given in the second section, with a special emphasis on how market concentration affects efficiency of the operation of retail enterprises and the state of the retail market of the Republic of Serbia. The third section describes the methodology used in the research, the research sample, the measurement variables, the research hypotheses, and the methods of testing the established hypotheses. The following chapter analyses the results of the conducted tests as well as the proposals and measures for establishing the homogeneity criteria. The final section summarizes the conclusions of the most important results, points to the shortcomings of the existing research and provides guidelines and proposals for future research.

\section{Literature review}

Recent academic studies have contradictory views on the consequences of market concentration (Barjaktarević, Filipović, \& Dimić, 2013). Drašković and Domazet (2008) state that market concentration is a natural outcome of competitive struggles leading to the fact that the most capable economic entities realize market power and certain benefits. Similarly, Pecotić-Kaufman and Slijepčević (2010) emphasize that market concentration to a certain extent is beneficial and positively affect the market, as on the one hand, there are companies trying to achieve as much profit as possible, but on the other hand, there are customers who are interested in lower prices of products and/or services they intend to buy. The authors emphasize the danger of shifting from a healthy concentration into a monopoly position. Díez-Vial (2007) and Ghemawat, \& Ghadar (2006) emphasize that market concentration results from the process of company integration and consider integration as a process that leads to a change in the individual market share, and therefore affects the overall market concentration. For instance, 
integration of two companies (through acquisition, merger, etc.) leads to a new entity, which has a share that equals the sum of shares of two previously integrated entities. As an advantage of such consolidation of business entities, Fuch, Kalfagianni, \& Arentsen, (2009) highlight the increase in efficiency that customers use in the form of lower prices and new and improved products and services. As the advantages of concentration, Inderst and Valletti (2011) include the acquisition of bargaining power of sellers in relation to suppliers, manufacturers, etc. Weyl and Fabinger (2013) and Gaudin (2016) consider them to be cost savings, easier forecast of market trends, etc.

Understanding the issue of market concentration implies a number of methodological and empirical challenges. Goodman et al. (2009) regard market concentration as the total number of sellers and buyers of a particular product, which are interconnected in close contact and as such affect the conditions under which others buy and sell. In order to understand market concentration in the best possible way, Hasting and Glibert (2005) point to the fact that it is necessary to understand the processes of integration that have led to a certain degree of concentration. In that context, the authors (Rickert, Schain, \& Stiebale, 2018; Gaudin, 2016; Pešić, 2015; Lovreta, 2009) point out that market concentration has horizontal, vertical and lateral dimensions, i.e. it is the result of three types of integration: 1) horizontal (within the same level of value chain), 2) vertical (within different levels of the value chain: forward integration, when a manufacturer takes over a retailer or backward integration), and 3) lateral (merging from different industries/branches). Horizontal concentration as a result of the horizontal integration process is expressed in absolute measures referring to coefficients such as $\mathrm{HHI}, \mathrm{CR}$, GINI index, etc. and market share. On the other hand, the vertical concentration is expressed in the degree to which one business unit conducts successive stages in the process of production, distribution and sales of products (Goodman et al., 2009).

For the retail sector, horizontal concentration has the most negative effects, which is confirmed by Stanicu's research (2015) carried out in the Romanian market, which shows that integration of retail facilities of the same level of value chain entails closing a large number of local stores, especially in rural areas, accompanied by an increase in unemployment rate. As the biggest threat from the horizontal market concentration on the example of Germany, Rickert, Schain and Stiebale (2018) point out the rise in retail prices after the merger of retail chains, which in some regions was up to $7.04 \%$ in supermarkets. Allain, Chambolle, Turolla, \& Villas-Boas (2017) and Argentesi, Buccirossi, Cervone, Duso, \& Marrazzo (2016) report a significant increase in retail prices as a result of the merger of French i.e. Dutch retail chains. 
On the other hand, the research conducted by Tansey and Raju (2017) on the US auto parts retail market, shows that the horizontal integration of business entities directly affects the growth of profitability and business result, with the fact that a high degree of market concentration leaves little room for maintaining prices at the level of market equilibrium. Direct correlation between market concentration and profitability was confirmed by the research carried out by Hovhannisyan and Bozic (2016), which showed that the integration of retail enterprises has a positive statistically significant effect on the performance of retailers, whereby with an increase in concentration of $10 \%$, there is an increase in the prices of dairy and food products in retail by $0.46 \%$.

In the Republic of Serbia, the biggest obstacle for establishing a favourable business environment is the high level of market concentration. Končar and Leković (2013) consider that concentration negatively affects the business activities of all sectors of the economy, especially of retail, as the grouping and integration of large trading companies changes the role and position of individual participants in value chains. Therefore, the relation between small and large retail chains is disturbed, as well as between production or supply and trade companies, where the losers are small retail chains, as well as the manufacturing enterprises and suppliers themselves due to pressure to lower purchase prices, increase rebates, introduce specialized fees, deferred payments, etc. Many authors (Stojanović, Stanišić, \& Veličković, 2010; Drašković, \& Domazet, 2008) systematized the negative sides of the increasing integration of certain trade companies in retail market of the Republic of Serbia, which are reflected in the growth of the price of products at the expense of customers, achievement of a large share in the total revenues of the entire industry to the detriment of competitors, the acquisition of bargaining power and securing more favourable conditions of procurement, realizing higher turnover and business income.

A standard indicator of the retail market concentration in literature (Petković et al., 2016; Pešić, 2015; Drašković, \& Domazet, 2008) are HerfindahlHirschman index $(H H I)$, Concentration ratio $(C R)$, GINI index, etc. $\mathrm{HHI}$ is defined as the sums of squares of the market share of each firm. The value of $\mathrm{HHI}$ less than 1 point shows a concentrated industry, between 1 and $1.8 \mathrm{a}$ moderate concentration, and over 1.8 high concentration. Observed in the period 2010-2016, the measured retail market of the Republic of Serbia shows a moderate concentration because the $\mathrm{HHI}$ value is about 1,340 points, a significant increase of $8.5 \%$ compared to 2012 , when the $\mathrm{HHI}$ value was about 1,256 points. Similar data on the market of the Republic of Serbia are also presented by CR concentration ratio, which is a market share of five $\left(\mathrm{CR}_{5}\right)$ or ten $\left(\mathrm{CR}_{10}\right)$ the largest companies within the given industry (Erkan, \& Sunay, 2018). In the retail sector, $C R$ ranges from $C_{5}=0.48 \%$ to $\mathrm{CR}_{10}=0.55 \%$, indicating a moderately concentrated market. As the last 
indicator of concentration, GINI index, showing the percentage of unequal share in the distribution of income, is about $30 \%$ in 2016 for the RS retail sector, which is somewhat above the average of EU member states.

Leading trading entities in Serbian market are primarily registered (with the Serbian Business Registers Agency) for performing retail activities, while simultaneously realizing activities in the wholesale and distribution sector. Given that financial statements do not show income separately from wholesale and retail, and that all selected entities in the sample perform their business in the same way, the available financial data for income of the observed commercial entities are used in this paper. Reliability of the research and methodological correctness was obtained by the reduction of total revenues and net profit of trading enterprises in relation to the number of employees. In this way, general business indicators are used as inputs for analysis, without emphasizing productivity and productivity per employee for retail or wholesale activities in sampled companies. The market concentration of the Republic of Serbia is presented in the following Table (Table 1).

Table 1. Retail market of the Republic of Serbia in the period 2010-2015

\begin{tabular}{|l|c|c|c|c|c|c|}
\hline $\begin{array}{l}\text { Business } \\
\text { income } \\
\text { (mil. RSD) }\end{array}$ & $\mathbf{2 0 1 0}$ & $\mathbf{2 0 1 1}$ & $\mathbf{2 0 1 2}$ & $\mathbf{2 0 1 3}$ & $\mathbf{2 0 1 4}$ & $\mathbf{2 0 1 5}$ \\
\hline $\begin{array}{l}15 \%+\text { individual } \\
\text { share } \\
\text { (top 3) }\end{array}$ & 163.763 & 171.238 & 185.756 & 195.530 & 199.667 & 192.938 \\
\hline Total share & $62 \%$ & $58 \%$ & $57 \%$ & $58 \%$ & $56 \%$ & $54 \%$ \\
\hline $\begin{array}{l}5-15 \% \\
\text { individual share } \\
\text { (3 firms) }\end{array}$ & 50.290 & 59.956 & 63.033 & 56.699 & 59.422 & 63.524 \\
\hline Total share & $19 \%$ & $20 \%$ & $19 \%$ & $17 \%$ & $17 \%$ & $18 \%$ \\
\hline $\begin{array}{l}1-5 \% \text { individual } \\
\text { share } \\
\text { (4 firms) }\end{array}$ & 14.014 & 19.105 & 24.299 & 29.644 & 33.748 & 35.208 \\
\hline Total share & $5 \%$ & $6 \%$ & $7 \%$ & $9 \%$ & $9 \%$ & $10 \%$ \\
\hline $\begin{array}{l}<1 \% \text { individual } \\
\text { share } \\
\text { (30 firms) }\end{array}$ & 36.981 & 46.010 & 52.574 & 57.371 & 63.166 & 68.405 \\
\hline Total share & $14 \%$ & $16 \%$ & $16 \%$ & $17 \%$ & $18 \%$ & $19 \%$ \\
\hline $\begin{array}{c}\text { TOTAL } \\
\text { (top 40) }\end{array}$ & $\mathbf{2 6 5 . 0 5 0}$ & $\mathbf{2 9 6 . 3 1 0}$ & $\mathbf{3 2 5 . 6 6 3}$ & $\mathbf{3 3 9 . 2 4 6}$ & $\mathbf{3 5 6 . 0 0 6}$ & $\mathbf{3 6 0 . 0 7 6}$ \\
\hline
\end{tabular}

Source: Authors' calculation - based on the data provided by Serbian Business Registers Agency

The table shows that out of the analysed sample of 40 trading companies in the period 2010-2015, three companies on average achieve a total market share of $57.3 \%$ in the realized turnover. The share of next three companies (individual share of $5-15 \%$ ) is around $18.3 \%$, while the share of a group of trading companies with an individual share is $1-5 \%$, but about $8 \%$ for a total of 
4 trading companies. The remaining 30 trade companies have a total market share of around $16.5 \%$. An unavoidable fact is that the retail market in the Republic of Serbia gravitates to the region of Vojvodina and the city of Belgrade, so the largest 3 retail chains are from this region (Vojvodina: Mercator; Bgd: Delhaize Maxi and Idea), while only one commercial company has a share of over $5 \%$ from Central-South Serbia (DIS DOO Krnjevo 7.5\%).

The presented differences in retail market concentration point to the conclusion that the retail sector of the Republic of Serbia is moderately to highly concentrated. The results of the previous research and the conducted analysis point to the need for empirical research and testing of the extent to which the differences in the degree of concentration of the retail sector are correlated to the differences in productivity and business result realized by retailers. How will the expected trend in the growth of the national market concentration affect the business performance of the leading retail chains, and how will it affect the survival and development of local retailers and independent retailers?

\section{Research Methodology}

The aim of the research is analysis of influence of market concentration measured by retail market share of selected trading companies at Serbian market on its productivity and business results. The correlation was tested at the level of the entire market of the Republic of Serbia and especially observed by regions at the level of: Vojvodina, the city of Belgrade and Central-South Serbia.

Basic research hypothesis $H_{1}$ reads: the differences in the market share of commercial enterprises on the market of the Republic of Serbia have a statistically significant impact on the differences in productivity (business income per employee) and business result (net result per employee) in the retail sector. The basic research hypothesis can be operationalized through three auxiliary hypotheses observed by statistical regions:

$\mathbf{H}_{1 \mathrm{a}}$ - there are statistically significant differences in productivity (business income per employee) and business result (net result per employee) between trading companies with small and big market share in retail sector of Vojvodina.

$\mathbf{H}_{\mathbf{1 b}}$ - there are statistically significant differences in productivity (business income per employee) and business result (net result per employee) between trading companies with small and big market share in retail sector of the city of Belgrade. 
$\mathbf{H}_{1 \mathrm{c}}$ - there are statistically significant differences in productivity (business income per employee) and business result (net result per employee) between trading companies with small and big market share in retail sector of CentralSouth Serbia.

The research was conducted on a sample of 40 largest retailers in the Serbian market*. The most important financial indicators of their business in the period from 2010 to 2015 were analysed, which were collected by analysing the financial statements from the website of the Serbian Business Registers Agency (SBRA). Data were collected during the second half of 2017. Collected data were processed with the statistical package SPSS 20. Based on previous research (Petković et al, 2016; Pešić, 2015), retailers are divided into four strata according to the size of the market share by realized income/turnover (up to $1 \%$, from $1 \%$ to $5 \%$, from $5 \%$ to $15 \%$, and more than $15 \%$ ). The sample of the research is presented in the following table (Table 2).

Table 2. Research sample

\begin{tabular}{|l|c|c|c|}
\hline $\begin{array}{l}\text { Concentration of } \\
\text { retailers }\end{array}$ & Number of retailers & $\begin{array}{l}\text { Structure of the } \\
\text { sample (\%) }\end{array}$ & $\begin{array}{l}\text { Total share in } \\
\text { retail (\%) }\end{array}$ \\
\hline $15 \%+$ & 3 & $7,5 \%$ & $57 \%$ \\
\hline $5 \%-15 \%$ & 3 & $7,5 \%$ & $18 \%$ \\
\hline $1 \%-5 \%$ & 4 & $10 \%$ & $8 \%$ \\
\hline $1 \%$ & 30 & $75 \%$ & $17 \%$ \\
\hline Total & $\mathbf{4 0}$ & $\mathbf{1 0 0} \%$ & $\mathbf{1 0 0} \%$ \\
\hline
\end{tabular}

Source: Authors' calculation

Dependent variables in the research were operationalized as the average of the earned business income per employee and the net result per employee in the period from 2010 to 2015 for the retailers covered by the research. In order to examine whether and to what extent retailers with different market shares differ in relation to business income per employee and the net result per employee, the One-way Analysis of Variance (ANOVA) was used, while descriptive statistics were used to display variables of measurement. Independent grouping variable is a market share as the main measure of market concentration.

\footnotetext{
* Delhaize Maxi, Veropoulos, Idea, Metro, Aman, Aroma marketi, Soulfood, Višnjica, Corner Shoop, Futura plus, Mercator, Univerexport-Trgopromet, Univerexport-import, BB Trade Persu, Angropromet, Podunavlje, Gomex, Sentapromet, Medius, Sinagoga, Mikromarket, Podunavlje Beočin, DIS Krnjevo, CDE S Interex, ES Komerc, Europrom, Fortuna market, Kastrum, Morava, Orion, Proleter, Tekijanka, Trnava, VP Dima, VUM, Alfa, Braća Popović doo, Metla komerc, Viva 92, Čutura Prokuplje.
} 
To test the auxiliary hypotheses, trading companies are classified by regions, where retailer's head office is located (the locations where they are registered and where they predominantly perform their activities). Within this research, the Republic of Serbia is divided into 3 statistically significant regions: Vojvodina, the city of Belgrade and Central-South Serbia.

\section{Results}

The impact of market share on retailers' productivity and business result was tested by the One-way Analysis of Variance, which actually shows whether the changes in the retailer's size (market share) are accompanied by changes in the basic financial indicators (operating income and net result per employee). The correlation was examined first for the entire market of the Republic of Serbia $\mathbf{H}_{1}$, and then for each region separately $\mathbf{H}_{1 \mathrm{a}}, \mathbf{H}_{1 \mathrm{~b}}$ and $\mathbf{H}_{\mathbf{1 c}}$. The following table (Table 3 ) illustrates the descriptive statistics for all four groups of retailers according to business income and net result per employee.

Table 3. Descriptive indicators for business income and net result per employee.

\begin{tabular}{|l|l|c|c|c|c|c|c|}
\hline \multicolumn{2}{|l}{ Variables/market share } & N & Mean & $\begin{array}{c}\text { Std. } \\
\text { Deviation }\end{array}$ & $\begin{array}{c}\text { Std. } \\
\text { Error }\end{array}$ & Min. & Max. \\
\hline \multirow{2}{*}{$\begin{array}{l}\text { Net result per } \\
\text { employee } \\
\text { (000.RSD) }\end{array}$} & $15 \%+$ & 3 & -620.5 & 254.4 & 146.9 & $-1,886$ & 216.2 \\
\cline { 2 - 8 } & $5 \%-15 \%$ & 3 & 209.1 & $1,167.6$ & 674.1 & -258 & 677.8 \\
\cline { 2 - 9 } & $1 \%-5 \%$ & 4 & 116 & 514 & 257.0 & -166 & 349.8 \\
\cline { 2 - 9 } & $1 \%$ & 30 & 230.5 & 315.1 & 57.5 & -323.5 & $1,323.3$ \\
\cline { 2 - 9 } & Total & 40 & 128.7 & 462.8 & 73.1 & $-1,886$ & $1,323.3$ \\
\hline \multirow{2}{*}{$\begin{array}{l}\text { Operating income } \\
\text { per employee } \\
\text { (000.RSD) }\end{array}$} & $15 \%+$ & 3 & $14,651.5$ & $1,740.1$ & $1,004.6$ & $11,095.5$ & $14,572.0$ \\
\cline { 2 - 8 } & $5 \%-15 \%$ & 3 & $12,880.2$ & $4,902.1$ & $2,830.2$ & $9,534.6$ & $19,306.3$ \\
\cline { 2 - 8 } & $1 \%-5 \%$ & 4 & $8,222.7$ & 4.695 & $2,347.5$ & $4,463.8$ & $15,089.3$ \\
\cline { 2 - 8 } & $1 \%$ & 30 & $9,774.4$ & $5,573.3$ & $1,017.5$ & $4,078.6$ & $27,197.6$ \\
\cline { 2 - 8 } & Total & 40 & $10,217.9$ & $5,366.3$ & 848.4 & $4,078.6$ & $27,197.6$ \\
\hline
\end{tabular}

Source: Authors' calculation

Table 3 shows that the highest income per employee is generated by retail chains that have the highest market share $(M=14,651.500)$. The most homogeneous $(\mathrm{min} / \mathrm{max})$ retailers in this group are the ones with a share of over $15 \%$. When it comes to the net result per employee, the table shows that the highest scores on the average are realized by retailers with market share of $1 \%(\mathrm{M}=230.500)$, while retail chains with a share of 1 to $5 \%$ are most homogeneous according to this testing variable. 
In order to test the basic research hypothesis $\mathbf{H}_{1}$ reading that differences in market share of retailers of the Republic of Serbia have a statistically significant influence on the differences in productivity and business result, the one-way analysis of variance (Table 4) was used, which shows that among four groups of retailers there is a statistically significant difference according to net result per employee $(F=3.353 ; p<0.05)$ and business income per employee $(F=4.575 ; p<0.01)$.

Table 4. Values of F-statistics

\begin{tabular}{|l|l|l|l|r|}
\hline Variables & $\mathbf{F}_{\text {stat. }}$ & $\mathbf{P}_{\text {value }}$ & \multicolumn{2}{|c|}{ Fcrit. $_{(\mathrm{a}=\mathbf{0}, \mathbf{0 1} ; \mathbf{\alpha}=\mathbf{0}, \mathbf{0 5})}$} \\
\hline Net result per employee & $3,353^{*}$ & 0,029 & 4,510 & 2,922 \\
\hline Operating income per employee & $4,575^{\star *}$ & 0,03 & 4,510 & 2,922 \\
\hline
\end{tabular}

${ }^{*}$ Sig. at $1 \%,{ }^{*}$ sig. at $5 \%$

Source: Authors' calculation

For the purpose of further confirmation of the obtained results, if the Post hoc test (Scheffe) is applied, it can be concluded that the largest statistically significant difference exists between companies that have up to $1 \%$ of market share and those that have over $15 \%$. Based on the testing, the conclusion is drawn that the basic research hypothesis $\mathbf{H}_{1}$ is accepted and that the differences in the size of market share of retailers statistically significantly affect the changes and differences in their productivity and business result, whereby the differences are most striking between the smallest and the largest group of retailers. Retailers are also divided by regions where they are registered and where they mainly perform their activities. The most companies are registered in Central Serbia and the least in Belgrade. Chisquare test examined whether there is a correlation between a region and the size of the firm. Certain tendencies confirm the existence of a correlation between the region and market share $(x 2=7.818, p=0.042<0.05)$. Table 5 shows that the largest percentage of enterprises with up to $1 \%$ of the market share is in Central and South Serbia, while the largest percentage of companies with share up to $15 \%$ are located in the region of Belgrade.

Table 5. Distribution of retailers by regions and market share

\begin{tabular}{|l|l|c|c|c|c|c|}
\hline \multicolumn{2}{|c|}{} & \multicolumn{3}{|c|}{ Market share per revenue } & \multirow{2}{*}{ Total } \\
\cline { 3 - 6 } \multicolumn{2}{|c|}{} & $\mathbf{1 5 \% +}$ & $\mathbf{5 \% - 1 5 \%}$ & $\mathbf{1 \% - 5 \%}$ & $\mathbf{1 \%}$ & \\
\hline \multirow{3}{*}{ Region } & Belgrade & $5.0 \%$ & $2.5 \%$ & $5.0 \%$ & $12.5 \%$ & $25.0 \%$ \\
\cline { 2 - 6 } & Vojvodina & $2.5 \%$ & $2.5 \%$ & $2.5 \%$ & $22.5 \%$ & $30.0 \%$ \\
\cline { 2 - 6 } & Central-South Serbia & $0 \%$ & $2.5 \%$ & $2.5 \%$ & $40.0 \%$ & $45.0 \%$ \\
\hline
\end{tabular}

Source: Authors' calculation 
To test the difference within a region, a one-way variance analysis was applied. The differences were first tested within the region of Vojvodina $\mathbf{H}_{\mathbf{1 a}}$. It was examined whether there are differences between retailers by market share for two dependent variables. Since there is only one retailer in three groups, it was not possible to apply the post-hoc Scheffe test. According to the net result per employee, there is a statistically significant difference between the groups $(F=5.028 ; p<0.05)$. Based on the descriptive statistics shown in Table 6, with the growth of the degree of concentration (market share), the net result per employee also increases. When realized income is tested against the number of employees, a statistically significant difference is also found $(F=38,721 ; p<0.01)$. According to the results in Table 6 , the growth of the share is accompanied with the increase in income per employee. Based on the analyses, the conclusion is drawn that the first auxiliary hypothesis $\mathbf{H}_{\mathbf{1 a}}$ is accepted and that differences in the size of market share of retailers in the Vojvodina region statistically significantly affect the productivity and business results.

Table 6. Descriptive statistics for the region of Vojvodina

\begin{tabular}{|l|l|c|c|c|c|c|c|}
\hline \multicolumn{2}{|l}{ Variables/market share } & N & Mean & $\begin{array}{c}\text { Std. } \\
\text { Deviation }\end{array}$ & $\begin{array}{c}\text { Std. } \\
\text { Error }\end{array}$ & Min. & Max. \\
\hline \multirow{2}{*}{$\begin{array}{l}\text { Net result per } \\
\text { employee } \\
(000 . R S D)\end{array}$} & $15 \%+$ & 1 & 231.2 & $/$ & $/$ & 231.2 & 231.2 \\
\cline { 2 - 9 } & $5 \%-15 \%$ & 1 & 207.8 & $/$ & $/$ & 207.8 & 207.8 \\
\cline { 2 - 9 } & $1 \%-5 \%$ & 1 & 151.3 & $/$ & $/$ & 151.3 & 151.3 \\
\cline { 2 - 9 } & $1 \%$ & 9 & 305.2 & 400.2 & 133.4 & 13 & $1,323.3$ \\
\cline { 2 - 9 } & Total & 12 & 269.7 & 347.6 & 100.4 & 13 & $1,323.3$ \\
\hline \multirow{2}{*}{$\begin{array}{l}\text { Operating income } \\
\text { per employee } \\
\text { (000.RSD) }\end{array}$} & $15 \%+$ & 1 & 12,973 & $/$ & $/$ & 12,973 & 12,973 \\
\cline { 2 - 8 } & $5 \%-15 \%$ & 1 & $9,534.6$ & $/$ & $/$ & $9,534.6$ & $9,534.6$ \\
\cline { 2 - 8 } & $1 \%-5 \%$ & 1 & $6,567.6$ & $/$ & $/$ & $6,567.6$ & $6,567.6$ \\
\cline { 2 - 8 } & $1 \%$ & 9 & $8,305.5$ & $6,049.5$ & $2,016.5$ & $4,078.6$ & $23,889.2$ \\
\cline { 2 - 8 } & Total & 12 & 8,652 & $5,373.7$ & $1,551.3$ & $4,078.6$ & $23,889.2$ \\
\hline
\end{tabular}

Source: Authors' calculation

Within the region of the city of Belgrade (Table 7), the lowest score is achieved by retailers with $1 \%$ to $5 \%$ of the market share, while the highest score is realized by a retail chain (Metro) which has between $5 \%$ and $15 \%$ of the market share. According to the results obtained by applying the ANOVA analysis, it can be said that there is a statistically significant difference between the size of market share and the realized income per employee in the region of Belgrade $(F=4.206 ; p=0.01)$. The difference was also obtained on the variable of net result per employee $(F=4.379, p<0.05)$. 
Vukmirović G., et al: Impact of Retail Market Concentration on Differences in Retailers'

Table 7. Descriptive statistics for the region of Belgrade

\begin{tabular}{|l|l|c|c|c|c|c|c|}
\hline \multicolumn{2}{|l|}{ Variables/market share } & N & Mean & $\begin{array}{c}\text { Std. } \\
\text { Deviation }\end{array}$ & $\begin{array}{c}\text { Std. } \\
\text { Error }\end{array}$ & Min. & Max. \\
\hline $\begin{array}{l}\text { Net result per } \\
\text { employee } \\
\text { (000.RSD) }\end{array}$ & $15 \%+$ & 2 & -996.4 & $1,258.1$ & 889.5 & $-1,886$ & -106.8 \\
\cline { 2 - 8 } & $5 \%-15 \%$ & 1 & -258 & $/$ & $/$ & -258 & -258 \\
\cline { 2 - 8 } & $1 \%-5 \%$ & 2 & -17.3 & 210.4 & 148.8 & -166.6 & 131 \\
\cline { 2 - 8 } & $1 \%$ & 5 & 53.6 & 426.1 & 190.5 & -323.5 & 711.8 \\
\cline { 2 - 8 } & Total & 10 & -201.8 & 667.7 & 211.1 & $-1,886.0$ & 711.8 \\
\hline \multirow{2}{*}{$\begin{array}{l}\text { Operating income } \\
\text { per employee } \\
\text { (000.RSD) }\end{array}$} & $15 \%+$ & 2 & $12,833.7$ & $2,458.2$ & $1,738.2$ & $11,095.5$ & 1,457 \\
\cline { 2 - 8 } & $5 \%-15 \%$ & 1 & $15,113.5$ & $/$ & $/$ & $15,113.5$ & $15,113.5$ \\
\cline { 2 - 8 } & $1 \%-5 \%$ & 2 & $5,616.9$ & $1,630.7$ & 1153 & $4,463.8$ & 6,770 \\
\cline { 2 - 8 } & $1 \%$ & 5 & $11,047.4$ & $9,364.5$ & $4,187.9$ & $4,739.1$ & $27,197.6$ \\
\cline { 2 - 8 } & Total & 10 & $10,725.1$ & $6,994.7$ & $2,211.9$ & $4,463.8$ & $27,197.6$ \\
\hline
\end{tabular}

Source: Authors' calculation

The table shows that the net result per employee carries a large negative score that can be attributed to retail chain Idea because of obvious illogical financial reporting and large disproportion between the realized income and the reported net loss in observed years. The largest statistically significant difference exists between retailers with a share of $5 \%$ to $15 \%$ and the remaining groups. On the basis of the conducted testing, it follows that the second auxiliary hypothesis $\mathbf{H}_{\mathbf{1 b}}$ is accepted, which implies that the differences in the size of market share statistically significantly affect the productivity and business results in the region of Belgrade.

In the region of Central-South Serbia, there were no respondents from the group with a market share above $15 \%$, and only one retail chain with a market share of $5 \%$ to $15 \%$, indicating a highly homogeneous region of the Serbian retail market. This is confirmed by the results: for the variable - net result per employee, statistically significant differences were not found $(F=0.241$, $\mathrm{p}=0.809)$, nor for variable - income per employee $(\mathrm{F}=3.071, \mathrm{p}=0.087)$. It is concluded that in the region of Central-South Serbia, the size of market share does not affect changes in productivity and business results, i.e. the third auxiliary hypothesis $\mathbf{H}_{1 \mathrm{c}}$ is rejected, and this tendency can be explained by the high degree of uniformity of retailers working in the region.

\section{Discussion}

On the basis of the conducted analyses and testing and confirmed research hypotheses, it proves that the retail market concentration and integration of retail chains statistically significantly influence the operations of commercial enterprises in the retail sector. The results were confirmed at the level of the 
entire market of the Republic of Serbia $\mathbf{H}_{1}$, as well as within the region of Vojvodina $\mathbf{H}_{1 \mathrm{a}}$ and the city of Belgrade $\mathbf{H}_{1 \mathrm{~b}}$, where the degree of concentration is the highest and where all three retailers are located with a market share greater than $15 \%$. In the region of Central-South Serbia, which is characterized by a homogeneous retail market (one retailer that has between $5 \%$ and $15 \%$ market share and no retailers with a market share of over $15 \%$ ), the established hypothesis $\mathbf{H}_{1 \mathrm{c}}$ is rejected. In the region of Vojvodina, the results show that, with the increase in the level of market share of retailers, the generated operating income per employee also increases, as well as the net result per employee. Similar tendencies are also present in the city of Belgrade, but an aggravating circumstance that influences a reliable conclusion is that Idea, which is at the same time the largest retailer in the region of Belgrade, measured by the realized income, reports large net losses in the financial statements in the whole observed period. The region of Central-South Serbia shows that with a higher level of homogeneity, the productivity and business results are balanced among retailers.

The results obtained confirmed the previous research (Rickert, Schain, \& Stiebale, 2018; Usova, 2017, Tansey, \& Raju, 2017; Petković et al, 2016; Pešić, 2015; Drašković, \& Domazet, 2008)) concluding that the concentration of the retail market leads to improvement of the retailers' business performance, which may have some negative consequences for retail chains with low market share. As a result of such tendencies in the market, small independent retailers face lower turnover, non-competitiveness, loss of market, higher costs, and reduced negotiating power in relations with manufacturers, suppliers and large retail chains. For customers, the problems caused by concentration are reflected in inadequate prices, lower discounts, rising unemployment, etc. Suppliers face greater risk of billing, less price difference, higher transport costs per unit of distributed goods, etc. All of the above adversely affects the economic development of the national market.

The main goal of the trade policy makers is to reduce the degree of concentration and achieve a homogeneous market through the entrance of a set of rules and procedures within existing legal solutions, which would limit the benefits of integration, prevent monopolistic and oligopolistic structures in the retail sector and which would strengthen, through tax reliefs and certain benefits for employment, the market position of small independent retailers. In addition, small retailers themselves need to optimize their activities and find ways to achieve, through more effective operation, the business results that are identical to large retail chains. This most frequently implies (Lukić, 2010; Lovreta et al, 2010; Lovreta, 2009): 1) an increase in revenue based on a reduction in the cost of servicing consumers using the CRM concept, 2) more efficient management of the margin; 3) reducing overall costs through the application of the modern cost management concept (TQM, continuous improvement, analysis of the supply chain, just in time delivery, etc.); 4) 
application of modern IT technology, etc. Such measures, along with the aforementioned guidelines, should be the primary instrument in the hands of the trade policy makers, which will reduce the level of concentration of the retail and enable the achievement of the homogeneous market of the Republic of Serbia.

\section{Conclusion}

The research of the degree of concentration of the retail market of the Republic of Serbia stems from the trend of retail chains integration, the internationalization of retail, and as a result, more significant changes in balance of power in the value chains to the detriment of small independent retailers. The conducted research showed a statistically significant correlation between the differences in the size of market share and productivity and the business results of the retailers. The dangers posed by the growth of concentration can affect the entire domicile market, and specific measures are defined that should serve commercial policy makers for achieving the balance of power in the retail market (through raising the degree of homogeneity) and establishing an equal competition.

The shortcomings of the research refer to: 1) the research is territorially limited exclusively to the retail market of the Republic of Serbia. The objective reason for this analysis is the author's familiarity with the mechanisms of retail operation in the domicile market and the availability of data; 2) productivity (income per employee) and business result (net result per employee) were tested in the conducted research as the main indicators of financial health of retailers, which may have led to simplified conclusions. The analysis of future research should include other financial indicators, such as: return on total assets $(R O A)$, return on equity $(R O E)$, inventory turnover, etc.

The analysis within the guidelines for future research should: 1) include a comparative analysis of the retail market of neighbouring countries $(B \& H$, Montenegro, Serbia, Croatia, Macedonia, etc.), 2) include a comparative analysis of the retail market of countries that are EU members (e.g. Slovenia, Croatia, Hungary, Romania, Bulgaria) and the Republic of Serbia. 3) expand to the indicators of the market potential of the region (e.g. number of employees, consumer basket, average net salary, purchasing power of the population, number of companies, etc.), in order to determine whether changes in the degree of concentration are accompanied by changes in the mentioned parameters, 4) cover a larger number of financial indicators (e.g. ROA, ROE, inventory turnover, etc.). The data obtained through such research would complement the scientific view of the significance and consequences of concentration and integration of retail chains to productivity, business results and the development of the retail sector. 
Vukmirović G., et al: Impact of Retail Market Concentration on Differences in Retailers'

\section{References}

Aalto-Setälä, V. (2002). The effect of concentration and market power on food prices: evidence from Finland. Journal of Retailing, 78(3), 207-216. doi:10.1016/s00224359(02)00073-8

Allain, M., Chambolle, C., Turolla, S., \& Villas-Boas, S.B. (2017). Retail Mergers and Food Prices: Evidence from France. The Journal of Industrial Economics, 65(3), 469-509. doi:10.1111/joie.12153

Argentesi, E., Buccirossi, P., Cervone, R., Duso, T., \& Marrazzo, A. (2016). The effect of retail mergers on variety: An ex-post evaluation. Technical report. Bologna: University of Bologna.

Bhattacharya, K. (2003). How Good is the BankScope Database? A Cross-Validation Exercise With Correction Factors for Market Concentration Measures. BIS Working Paper, 133, 1-21. doi:10.2139/ssrn.901147

Díez-Vial, I. (2007). Explaining vertical integration strategies: market power, transactional attributes and capabilities. Journal of Management Studies, 44(6), 1017-1040.

doi.org/10.1111/j.1467-6486.2007.00693.x

Drašković, B., \& Domazet, I. (2008). Koncentracija tržišne moći kao izraz nesavršenosti tržišta. In Tržišne strukture i zaštita konkurencije - iskustva zemalja u tranziciji. Beograd: Institut ekonomskih nauka / Beogradska bankarska akademija. pp. 45-83.

Erkan, B., \& Sunay, Z.F. (2018). Russia's market and product-based export diversification. Journal of Life Economics, 5(3), 43-60. doi.org/10.15637/jlecon.252.

Fuchs, D., Kalfagianni, A., \& Arentsen, M. (2009). Retail Power, Private Standards, and Sustainability in the Global Food System. In J. Clapp \& D. Fuchs (Eds.), Corporate Power in Global Agrifood Governance. (pp. 28-59). MIT Press - Journals. doi:10.7551/mitpress/9780262012751.003.0002

Gaudin, G. (2016). Pass-through, vertical contracts, and bargains. Economics Letters, 139, 1-4. doi:10.1016/j.econlet.2015.11.043

Ghemawat, P., \& Ghadar, F. (2006). Global integration $\neq$ global concentration. Industrial and Corporate Change, 15(4), 595-623. doi.org/10.1093/icc/dtl013.

Goodman, C., Kachur, S.P., Abdulla, S., Bloland, P., \& Mills, A. (2009). Concentration and drug prices in the retail market for malaria treatment in rural Tanzania. Health Economics, 18(6), 727-742. doi:10.1002/hec.1473

Hastings, J. S., \& Gilbert, R. J. (2005). Market power, vertical integration and the wholesale price of gasoline. The Journal of Industrial Economics, 53(4), 469-492. doi.org/10.1111/j.1467-6451.2005.00266.x.

Hovhannisyan, V., \& Bozic, M. (2016). The effects of retail concentration on retail dairy product prices in the United States. Journal of Dairy Science, 99(6), 4928-4938. doi:10.3168/jds.2015-10410

Inderst, R., \& Valletti, T.M. (2011). Buyer Power And The 'Waterbed Effect'. The Journal of Industrial Economics, 59(1), 1-20. doi:10.1111/j.14676451.2011.00443.x 
Vukmirović G., et al: Impact of Retail Market Concentration on Differences in Retailers'

Končar, J., \& Leković, S. (2013). Trendovi modernizacije i strukturne transformacije trgovine u funkciji održivog razvoja. Anali Ekonomskog fakulteta u Subotici, 49(29); 407-419.

Lovreta, S., Končar, J., \& Petković, G. (2009). Kanali marketinga. Beograd: Ekonomski fakultet u Beogradu - Centar za izdavačku delatnost

Lovreta, S., \& ed., (2009). Strategija razvoja trgovine republike Srbije. Beograd: Ekonomski fakultet u Beogradu.

Lovreta, S., Berman, B., Petković, G., Veljković, S., Crnković, J., \& Bogetić, Z. (2010). Customer Realationship Management. Beograd: Ekonomski fakultet u Beogradu / Data Status.

Lukić, R. (2010). Analiza profitabilnosti trgovine u Srbiji. Škola biznisa, 15-23; 4.

Panagiotou, G. (2006). The impact of managerial cognitions on the structure-conductperformance (SCP) paradigm: A strategic group perspective. Management Decision, 44(3), 423-441. doi.org/10.1108/00251740610656296.

Pecotić-Kaufman, J., \& Slijepčević, S. (2010). Koncentracije poduzetnika i mjerodavno tržište: Pravni i ekonomski aspekti. Zbornik Pravnog fakulteta u Zagrebu, 60(5), 995-1045. https://hrcak.srce.hr/59892..

Pešić, S. (2015). Koncentracija u trgovini na malo kao determinanta profitabilnosti maloprodajnih preduzeća. Beograd: Ekonomski fakultet. PhD Thesys.

Petkovic, G., Lovreta, S., Pindzo, R., \& Pesic, S. (2016). Evaluating the concentration in Serbian tourism and FMCG retail sector. Ekonomika preduzeca, 64(1-2), 187198. doi:10.5937/ekopre1602187p

Rickert, D., Schain, J.P., \& Stiebale, J. (2018). Local market structure and consumer prices: Evidence from a retail merger. DICE Discussion Paper, 1-47; 280; http://hdl.handle.net/10419/173247.

Statistical office of the Republic of Serbia (2007). Statistical Yearbook. Beograd.

Stojanović, B., Stanišić, T., \& Veličković, M. (2010). Problem zaštite konkurencije u trgovini na malo u Srbiji. Škola biznisa,57-66; 3

Tansey, M., \& Raju, S. (2017). Pricing, concentration and public policy: The U.S. automobile market. Journal of Policy Modeling, 39(5), 762-774. doi:10.1016/j.jpolmod.2017.07.004

Usova, N.V. (2017). Identification of consumer development trends in a major city: a market-based approach. R-economy, 3(1),

50-58. doi:10.15826/recon.2017.3.1.006

Weyl, E.G., \& Fabinger, M. (2013). Pass-Through as an Economic Tool: Principles of Incidence under Imperfect Competition. Journal of Political Economy, 121(3), 528-583. doi:10.1086/670401 